\title{
The Built Environment and Mental Health
}

\author{
Gary W. Evans
}

ABSTRACT The built environment has direct and indirect effects on mental health.Highrise housing is inimical to the psychological well-being of women with young children. Poor-quality housing appears to increase psychological distress, but methodological issues make it difficult to draw clear conclusions. Mental health of psychiatric patients has been linked to design elements that affect their ability to regulate social interaction (e.g., furniture configuration, privacy). Alzheimer's patients adjust better to small-scale, homier facilities that also have lower levels of stimulation. They are also better adjusted in buildings that accommodate physical wandering. Residential crowding (number of people per room) and loud exterior noise sources (e.g., airports) elevate psychological distress but do not produce serious mental illness. Malodorous air pollutants heighten negative affect, and some toxins (e.g., lead, solvents) cause behavioral disturbances (e.g., self-regulatory ability, aggression). Insufficient daylight is reliably associated with increased depressive symptoms.

Indirectly, the physical environment may influence mental health by altering psychosocial processes with known mental health sequelae. Personal control, socially supportive relationships, and restoration from stress and fatigue are all affected by properties of the built environment. More prospective, longitudinal studies and, where feasible, randomized experiments are needed to examine the potential role of the physical environment in mental health. Even more challenging is the task of developing underlying models of how the built environment can affect mental health. It is also likely that some individuals may be more vulnerable to mental health impacts of the built environment. Because exposure to poor environmental conditions is not randomly distributed and tends to concentrate among the poor and ethnic minorities, we also need to focus more attention on the health implications of multiple environmental risk exposure.

Human beings spend more than $90 \%$ of their lives indoors, ${ }^{1}$ yet we know much more about ambient environmental conditions and health than we do about the built environment and health. This article critically analyzes what is known about the built environment and mental health. The built environment affects mental health in two major ways. Characteristics of the built environment can directly influence mental health. Environmental characteristics with direct effects on mental health include housing, crowding, noise, indoor air quality, and light.

In addition to direct effects, the built environment can indirectly impact mental health by altering psychosocial processes with known mental health consequences. For example, higher residential density interferes with the development of socially supportive relationships within the household. Diminished social support increases

Dr. Evans is with the Departments of Design and Environmental Analysis and Human Development, Cornell University.

Correspondence: Gary Evans, Department of Design and Environmental Analysis and Department of Human Development, Cornell University, Ithaca, NY 14853-4401. (E-mail: gwe1@cornell.edu) 
psychological distress. The indirect pathways I examine are personal control, social support, and restoration. Following discussion of indirect mental health correlates of the built environment, conceptual challenges and future research needs are outlined.

\section{DIRECT MENTAL HEALTH CORRELATES OF THE BUILT ENVIRONMENT}

\section{Housing}

Most research on housing and health has focused on physical health. ${ }^{2,3}$ Nonetheless, house type (e.g., high-rise), floor level, and housing quality (e.g., structural problems) have all been linked to mental health.

House Type Studies on house type converge on the conclusion that high-rise, multiple dwelling units are inimical to the psychological well-being of mothers with young children and possibly that of young children themselves. ${ }^{4-6}$ These effects seem particularly pronounced among low-income families. Nearly all of these studies employ cross-sectional designs with statistical controls for socioeconomic status (SES). They tend to rely on self-report measures of psychological distress that incorporate subclinical symptoms of anxiety and depression. A small number of studies have taken advantage of natural experiments in which tenants were randomly assigned to dwellings. $^{7-9}$

Suspected reasons for the link between high-rise housing and psychological distress are social isolation of mothers and restricted play opportunities for children. In many high-rise buildings, particularly for low-income families, insufficient resources are allotted to spaces that afford the development and maintenance of social networks. Lobbies, lounges, and other small-group spaces are absent or located too far from residences or in public areas that afford insufficient residential control and feelings of ownership (e.g., public lobby upon entrance). Women in large, high-rise housing developments report more loneliness and diminished territorial control in comparison to women of similar backgrounds living in other types of housing. ${ }^{4,6}$

Parents of young children in large multiple-dwelling units often cope with the paucity of nearby play spaces by keeping children inside their apartments. Such restrictions heighten intrafamilial conflict, minimize play opportunities with others, and remove a primary avenue for parents to get to know their neighbors. ${ }^{10,11}$

Floor Level Some of the adverse mental health consequences of high-rise housing may be caused by floor level itself. Families living on higher floors have more mental health problems. However, all of the studies showing this, save one, ${ }^{7}$ are crosssectional. ${ }^{4,6}$ Thus, the potential methodological problem of self-selection bias is a plausible rival explanation. People with greater preexisting mental health problems may wind up living on higher floor levels.

Housing Quality Housing quality, which typically incorporates some aspects of structural quality, maintenance and upkeep, amenities (e.g., private bath, central heat), and physical hazards, is positively associated with mental health. Although there is near consensus on an inverse relationship between housing quality and psychological distress, ${ }^{4-6,12}$ a host of methodological problems plagues this literature. 
Most housing quality and mental health study designs are cross-sectional, and too many rely on respondent reports of housing quality. Although many investigators have employed statistical controls for SES, other "third" variables could be operating that are not adequately captured by SES controls. In addition, since psychological well-being can affect one's judgment about environmental quality, some of the apparent correlation between housing quality and well-being may be spurious. For example, people who are depressed might rate their housing quality lower than others not suffering psychological distress. On the other hand, some authors ${ }^{12-15}$ have shown that when people move into better housing, their mental health improves in comparison to those who do not move.

Some methodological problems may lead to the opposite bias, causing underestimation of housing-mental health relationships. For example, many housing quality studies have focused on low-income or institutional (e.g., military, college dorms) populations. Variability in housing quality for such populations is truncated, thus downwardly biasing estimates of covariation with health outcomes. Furthermore, housing quality assessment instruments often contain few items, some of which are dichotomous (e.g., present/absent), and rarely incorporate reliability estimates. Christenson et al. ${ }^{16}$ compared associations between indices of housing quality and residential satisfaction, demonstrating significant increments in explained variance ( $8 \%$ to $19 \%)$ by improving the reliability of housing quality measurement instruments.

A few explanations for the positive link between housing quality and mental health have been offered. Insecurity often accompanies poor-quality housing. There are constant difficulties with repairs and unresponsive landlords. The occupants of poor-quality housing are often low-income renters who are concerned about housing tenure. Frequent relocations, which occur more often among people living in poor-quality housing, are a risk factor for socioemotional problems in children. ${ }^{17,18}$ Involuntary relocation negatively affects psychological adjustment among older ${ }^{19}$ and middle-aged adults ${ }^{20}$ as well. People living in poor-quality housing experience stigma and may attribute some of their predicament to themselves. ${ }^{12,21}$ Parents in poor housing are more apt to contend with safety hazards including insufficient safety protection (e.g., smoke detectors, hot water temperature regulators), close proximity to higher volume street traffic, and a greater number of housing code violations, all of which contribute to childhood injury rates. ${ }^{22-25}$

Neighborhood Quality When people change houses, they often move to new neighborhoods as well. Evaluations of three recent experiments with housing voucher programs for low-income families in the United States, including one with random assignment, show that relocating from low-income neighborhoods to middleincome areas is associated with enhanced mental health for both adults and children. ${ }^{26,27}$

It is difficult to disentangle the quality of the residential unit from the neighborhood context in which the housing is situated. For example, multiple-family dwellings are more likely to be proximate to busy streets. ${ }^{24}$ Poor-quality housing is more likely to be located in neighborhoods with multiple indicators of urban decay. ${ }^{28,29}$ There is growing literature demonstrating that neighborhood quality has mental health impacts on children and their families, independent of household SES. ${ }^{29,30}$ Unfortunately, none of these studies specifies physical qualities of neighborhoods, instead defining neighborhood quality as a bundled index of multiple social (e.g., percentage unemployed) and physical attributes (e.g., number of abandoned build- 
ings). Recently, Weich et al. ${ }^{31}$ found that housing areas with deck access had higher rates of depression. Deck access residences are multifamily units in which individual apartments open directly onto open walkways connected to a central staircase. These walkways are rather public, anonymous spaces with little evidence of residential social control or ownership.

\section{Institutional Settings}

Vulnerable members of society who cannot live on their own may reside in institutional environments. There is a small body of research on design and mental health among residents of psychiatric facilities and residences for Alzheimer's patients, respectively.

Psychiatric Facilities When furniture is rearranged to promote social interaction (e.g., chairs facing one another at a comfortable distance, chairs arranged around a table), social interaction among hospitalized patients increases, and isolated, passive behaviors decrease. ${ }^{32-35}$ Timko $^{36}$ showed that better physical amenities in psychiatric facilities (e.g., hallway decorations, weather protection at entryways) were significantly related to multiple indicators of psychological adjustment.

The above institutional studies focused on psychiatric facilities. Zimring et al. ${ }^{37}$ had the opportunity to evaluate architectural renovations in a hospital for the developmentally disabled. Large open sleeping wards that typically accommodated 15 to 20 severely retarded adults were renovated into three different residential designs: suites, small corridors, and open sleeping wards that had modular, partially (half height) partitioned spaces. The open wards resembled in many respects an open office design. Improvements (e.g., social interaction, mental alertness) were found pre- to postconstruction for those living in the suites and corridors, whereas little change occurred in the partitioned open sleeping ward. Zimring's data are consistent with prior work showing that the more individuals a psychiatric patient shares a bedroom with, the greater the amount of social withdrawal. ${ }^{38}$ Patients with their own rooms are better adjusted and more socially engaged.

Alzheimer's Facilities Although a new, emerging area of research, there is evidence that design can make a difference in the well-being of Alzheimer's patients. Among the design features best documented with positive mental health outcomes including less depression, less disorientation, and reductions in behavioral disturbances are the following: smaller (9-20 residents) versus larger units, reduction in noise levels, use of simple geometric floor plans, landmarks and good signage, accommodation of wandering, and provision of noninstitutional, more homelike features. ${ }^{39}$ The latter may be particularly effective if design elements from the historical period matching the individual's middle adulthood are incorporated. ${ }^{40}$ Unfortunately, nearly all of these studies suffer from weak research designs, often lacking appropriate controls.

\section{Crowding}

Examination of the literature reveals a positive relationship between one index of crowding, number of people per room, and psychological distress. Indices of crowding measured in the aggregate such as people per census tract bear little relationship to mental health outcomes. ${ }^{41,42}$ Furthermore, in measuring number of people per room, it is important to exclude people living alone, since single residence is a welldocumented correlate of mental illness.

The data on number of people per room and psychological distress are consis- 
tent with the few insignificant findings likely due to truncated range in density and/ or poor measurement of mental health. Experimental studies with random assignment to short-term crowding in the laboratory reveal significant impacts on negative affect as well as physiological stress. ${ }^{41,42}$ Investigations of institutionalized populations (e.g., prisoners) evidence associations between crowding and psychological distress. ${ }^{43}$ Tripling up of college students also reveals similar trends. ${ }^{42}$ One of the prison studies included longitudinal data, with changes in prison cell density coinciding with fluctuations in well-being. ${ }^{44}$ Several residential density studies also reveal evidence of a dose-response relationship. ${ }^{45-47}$ Furthermore, a prospective, longitudinal study revealed that although residential density was not related to psychological distress at initial occupancy, 6 months later it was positively related to elevated psychological distress. ${ }^{48}$ Children also evidence adverse mental health correlates of residential crowding. ${ }^{42}$

\section{Noise}

Most research on noise and mental health has examined airport noise exposure. Initial research focused on psychiatric admissions, with early studies supporting a positive association between aircraft noise exposure and elevated psychiatric admissions. Subsequent work with better controls for socioeconomic status has largely refuted this earlier literature. ${ }^{49}$ There is evidence, however, that community noise exposure from airports may be associated with less catastrophic indices of psychological well-being than psychiatric admissions. Unfortunately, most of these studies on psychological distress are cross-sectional, although many incorporate statistical controls for SES. ${ }^{42,49}$ A study of children exposed to traffic noise from roads and trains in small towns in Austria generated a dose-response function between noise and psychological distress. ${ }^{50}$ These investigators also uncovered greater adverse impact among children at higher biological risk (e.g., prematurity). One prospective study with children indicated that 8- to 10-year-olds' psychological health was adversely impacted by the opening of a new airport. ${ }^{51}$ There are also data indicating dose-response functions between airport noise and use of psychotropic drugs in adults. $^{52,53}$ On the other hand, studies around Heathrow Airport have found more equivocal data on noise and children's mental health. ${ }^{54-56}$

\section{Indoor Air Quality}

Epidemiologists and physicians studying air pollution and health were among the first to appreciate that environmental problems in the built environment were not equivalent to outdoor ambient conditions. Chemical properties of building materials themselves can be toxic, and heating and cooking systems affect indoor air quality. As an illustration, an unvented gas stove raises indoor nitrogen dioxide concentrations above typical outdoor levels. Building properties (e.g., ventilation, construction materials) can also alter exposure to ambient pollutants. Ozone levels, for example, are usually lower indoors than outside.

Malodorous Pollutants Research on indoor pollutants and mental health has focused on malodorous substances and various behavioral toxins (e.g., lead, solvents, pesticides). It is worth brief mention that outdoor ambient pollutants have been associated with mental health outcomes. ${ }^{57,58}$ The evidence includes large crosssectional comparisons and longitudinal studies, including some time series analyses. There is consistent evidence of elevated negative affect under well-controlled laboratory experiments and in field studies of malodorous pollutants. ${ }^{58-60}$ Negative be- 
havioral reactions (e.g., aggression) to pollutants also occur under certain conditions. ${ }^{58,59}$

Behavioral Toxins Most research on behavioral toxins such as heavy metals, pesticides, and solvents has focused on neurological and cognitive impacts. ${ }^{61}$ Studies of cognitive deficits associated with early childhood lead exposure are a prime example. ${ }^{62,63}$ It is less well appreciated that several of the behavioral toxins, including lead, also impact psychological well-being. Lead, for example, impedes self-regulatory behavior in children (e.g., focused attention, frustration tolerance), which in turn is related to behavioral conduct disorders such as yelling, fighting, and other forms of aggression. ${ }^{62,64}$ Several other hazardous materials (mercury, manganese, organic solvents) produce neuropsychiatric symptoms including anxiety, depression, irritability, and concentration difficulties. ${ }^{65}$ Exposure to heavy metals has also been linked to criminal behavior in adults, ${ }^{66}$ but the evidence comes from only a few correlational studies. Animal toxicological models also reveal evidence of aggression and deficient maternal behavior. ${ }^{67}$

Psychological Trauma From Hazardous Exposure Some behavioral reactions to toxins are caused by the psychological trauma associated with threats to personal health. Community members who discover they have been exposed to hazardous materials reveal multiple indices of psychological distress including fear and panic, sleep disturbance, feelings of loss of control and helplessness, pessimism and fatalism (particularly with respect to future health), and in some cases posttraumatic stress disorder. ${ }^{68,69}$ Heightened family conflicts are also common.

\section{Light}

Despite widespread belief, there is no clear evidence that color affects mood, emotions, or psychological well-being in any systematic manner. There is consistent evidence on color preferences, but emotional reactions to color are idiosyncratic and transitory. Levels of illumination, particularly the amount of daylight exposure, however, impact psychological well-being.

Seasonal affective disorder (SAD) is a form of depression that occurs in relation to the amount of exposure to daylight. ${ }^{70}$ Individuals chronically exposed to shorter hours of daylight suffer more sadness, fatigue, and, for some, clinical depression. Patients hospitalized for severe depression recover more quickly in sunny versus dimly lit rooms. ${ }^{71}$ Level of illumination and not spectral frequency is the critical element in SAD. ${ }^{72}$ Insufficient exposure to daylight from windows in a Swedish study disrupted normal circadian rhythms of cortisol in school children. Distractibility and cooperative social behavior in the classroom were also adversely affected. ${ }^{73}$

\section{Summary}

Table 1 provides an overview of the direct effects of the physical environment on mental health.

\section{INDIRECT MENTAL HEALTH CORRELATES OF THE BUILT ENVIRONMENT}

There are indirect pathways that may account for how the built environment influences mental health. Three psychosocial processes affected by the built environment 
TABLE 1. Direct mental health effects of the physical environment

\begin{tabular}{|c|c|c|c|}
\hline Environmental characteristics & Mental health impacts & Assessment of the evidence & References \\
\hline High-rise housing & $\begin{array}{l}\text { Elevated psychological distress, especially } \\
\text { among low-income mothers. }\end{array}$ & $\begin{array}{l}\text { Consistent and includes data from random- } \\
\text { ized field studies. } \\
\text { Some but not all studies control for SES. }\end{array}$ & $4-6$ \\
\hline Residential floor level & $\begin{array}{l}\text { Adults living on higher floors have more psy- } \\
\text { chological distress. }\end{array}$ & $\begin{array}{l}\text { Inconsistent and all cross-sectional. A few } \\
\text { studies control for SES. }\end{array}$ & $4-7$ \\
\hline $\begin{array}{l}\text { Housing quality (structural defects, hazards, } \\
\text { poor maintenance, climatic problems (e.g., } \\
\text { heat, humidity) }\end{array}$ & $\begin{array}{l}\text { Greater psychological distress in housing of } \\
\text { poorer quality. }\end{array}$ & $\begin{array}{l}\text { Consistent but largely based upon cross-sec- } \\
\text { tional evidence, although most have SES } \\
\text { controls. A few longitudinal studies show } \\
\text { similar patterns. }\end{array}$ & $4-6,12$ \\
\hline $\begin{array}{l}\text { Neighborhood quality (aggregate bundle of } \\
\text { social and physical attributes) }\end{array}$ & $\begin{array}{l}\text { Greater psychological distress and poorer cog- } \\
\text { nitive development in children. }\end{array}$ & $\begin{array}{l}\text { Consistent and mainly cross-sectional. Recent } \\
\text { randomized experiment relocating low-in- } \\
\text { come families into better quality neighbor- } \\
\text { hoods reveals similar effects. }\end{array}$ & $26,27,29-31$ \\
\hline $\begin{array}{l}\text { Furniture placement (at social distances, } \\
\text { around tables) }\end{array}$ & $\begin{array}{l}\text { Increased social interaction and reduced pas- } \\
\text { sive, isolated behaviors in psychiatric pa- } \\
\text { tients. }\end{array}$ & Consistent and includes intervention studies. & $32-25$ \\
\hline Privacy (architecture, single rooms) & $\begin{array}{l}\text { Severely retarded adults and psychiatric pa- } \\
\text { tients reveal better functioning with more } \\
\text { ability to regulate social interaction. }\end{array}$ & Consistent but small number of studies. & 37,38 \\
\hline $\begin{array}{l}\text { Alzheimer's facilities (smaller scale units, } \\
\text { more homelike, less noise, accommoda- } \\
\text { tion of wandering) }\end{array}$ & $\begin{array}{l}\text { Improved functioning, including less disorien- } \\
\text { tation, fewer behavioral problems. }\end{array}$ & $\begin{array}{l}\text { Small number of studies, some without con- } \\
\text { trol groups. }\end{array}$ & 39 \\
\hline
\end{tabular}


Residential density (people/room)

Noise (aircraft)

Indoor air quality

Light
More negative affect, greater psychological distress. Psychiatric disorder not related to crowding. Areal indices such as people per census tract unrelated to mental health.

Unrelated to psychiatric disorder. Elevated psychological distress in children.

Malodorous pollutants linked to negative affect. Behavioral toxins related to acting

out, aggression. Community contamination reliably related to trauma.

No reliable impacts of color. Levels of illumination but not spectrum effect depression.
Consistent and includes lab studies, cross-sectional data, and dose-response functions, and one prospective field study. Most statistically control for SES.

Mixed data, but one prospective study and some dose-response data for children's psychological distress.

Many incorporate SES controls.

Consistent data for malodorous air but only small number of behavioral toxicology studies. Several analyses of trauma in contaminated communities, primarily case study designs.

Consistent clinical and experimental data for illumination level impacts. Hormonal pathways reasonably well characterized.

SES, socioeconomic status. 
are personal control, social support, and restoration. Each of these processes, in turn, has well-characterized mental health sequelae.

\section{Personal Control}

People feel better and have better mental health when they can control their surroundings. ${ }^{74-76}$ When opportunities for control over the environment are thwarted, helplessness can occur. Helplessness is operationalized by exposing subjects to an uncontrollable stimulus (e.g., noise) while performing a task and then presenting them with opportunities to avoid a noxious stimulus by performance on either the same or a different task. In another learned helplessness paradigm, individuals are exposed to an uncontrollable stimulus, followed by a different task wherein the aversive stimulus is no longer present. In each case, greater helplessness is indicated by reduced persistence (giving up) on the subsequent task.

Several studies have directly linked the built environment to helplessness. Laboratory exposure to acute noise, ${ }^{77-79}$ crowding, ${ }^{80-82}$ and malodorous pollutants ${ }^{59}$ cause learned helplessness in people. Chronic exposure to community noise ${ }^{42,51,83-85}$ reveals the same patterns of results among elementary school children. Cohen et al., ${ }^{83}$ for example, found cross-sectional and longitudinal evidence of diminished task persistence on a challenging jigsaw puzzle among third through fifth graders attending schools in areas affected by airport noise in comparison to children in similar schools located in quiet neighborhoods. Extensive SES controls were incorporated in Cohen and colleagues' work. Bullinger et al. ${ }^{51}$ replicated these effects in a prospective, longitudinal study using the opening of a new airport. Acoustical improvements in a noisy preschool building led to greater task persistence. ${ }^{86}$ Adults who live in more crowded neighborhoods ${ }^{87}$ and children in more crowded housing ${ }^{42,88,89}$ manifest greater helplessness in task persistence.

Architecture may impact helplessness as well. College students in dormitories with long corridor designs manifest multiple indices of helplessness in comparison to those living in suite arrangements. ${ }^{90-92}$ Students were randomly assigned to living units and the greater the duration of residence, the stronger the impact. Uncontrollable social interaction appears to explain these design effects. High-rise housing and poor-quality housing have also been associated with more uncontrollable social interaction. ${ }^{93,94}$

Other design features may influence the regulation of social interaction. The provision of a range of social interaction spaces from small intimate spaces for solitude, through small group spaces, to larger, more public interaction opportunities is associated with greater perceived control and comfort in residential settings. ${ }^{95,96}$ The size, location, and permeability of interior rooms influence the degree of social control afforded to residents. ${ }^{97,98}$

Territoriality, the ability to monitor and regulate use of space, is related to the physical environment. Tall, large structures, long interior corridors, lack of small group spaces, and poor visual surveillance capability (e.g., inability to monitor entrances, places for concealment) interfere with territorial control and feelings of ownership, and are associated with both actual crime levels and fear of crime. ${ }^{99-102}$ Social cohesion among neighbors along with willingness to exert social control over the behaviors of others constitute collective efficacy. Collective efficacy is related to actual crime as well as fear of crime. ${ }^{103}$ When public housing residents relocate to middle-class suburban neighborhoods, feelings of mastery increase relative to other public housing residents who relocate to low-income neighborhoods. ${ }^{104}$ 


\section{Social Support}

A second indirect pathway potentially linking the built environment to mental health is social support. A multitude of empirical studies reflect positive relationships between social support and mental health. ${ }^{105-108}$ Cross-sectional, prospective, and longitudinal studies and intervention experiments all converge on this conclusion.

There are multiple ways in which the built environment can influence the development and maintenance of socially supportive networks. The probability of social interaction is greater when entrances to residential units are proximate, face one another, or are directly connected to major pedestrian paths or meeting areas. ${ }^{109,110}$

Social interaction is also promoted inside buildings by proximity (e.g., nearby offices $)^{111-113}$ and by creating focal points. Successful focal points include neutral territory, visual prospect (i.e., one can see what is happening in the space prior to making a behavioral commitment to the space), inclusion of activity generators (e.g., food), and furniture arrangements that encourage social interaction. ${ }^{111,114}$ Many of these same design features also facilitate positive social interaction in outdoor plazas and social spaces. ${ }^{15,116}$

More crowded residential settings (i.e., higher number of people per room) cause social withdrawal and impair the development and maintenance of socially supportive relationships. Evidence includes cross-sectional and prospective longitudinal field studies as well as experimental studies in the laboratory. ${ }^{42,117}$ There are also several studies of parent-child interaction indicating more conflict and less responsive parenting in more crowded homes. ${ }^{42}$

Analogous findings have also been uncovered in high-rise housing developments in comparison to low-rise units or detached homes. ${ }^{8,93,118,119}$ Residents on busy streets, compared to those living on streets with lower traffic volume, are more socially withdrawn and less likely to know their neighbors. ${ }^{120}$ All of these studies incorporated controls for SES.

Irritability and negative affect are increased by exposure to noise both at home and at work. ${ }^{121-123}$ Noise can potentiate the expression of aggression, and people exposed to noise are significantly less likely to help others in need of assistance. ${ }^{124}$ Noise interferes with communication, which is undoubtedly a component of social support. Pollutants increase negative affect, irritability, and, under some circumstances, aggression. No data directly address the relationship between either noise or pollution exposure and social support, but such pathways are plausible.

\section{Restoration}

A third indirect pathway through which the built environment might influence mental health is restoration. Several properties of the physical environment have been directly linked to recovery from cognitive fatigue and stress. Laboratory and field studies have demonstrated that exposure to natural elements such as trees, water, and natural landscapes replenishes cognitive energy. Self-report and cognitive performance data converge on this conclusion. ${ }^{125-127}$ Psychophysiological recovery from experimental and naturalistic stressor exposure is also facilitated by exposure to natural elements. ${ }^{128,129}$ In addition, views of nature ${ }^{125}$ and landscape paintings, ${ }^{129}$ as well as indoor plants, ${ }^{130}$ are all associated with increased positive affect and comfort. Recovery from surgery in a randomized trial was accelerated by hospital window views of nature, ${ }^{131}$ and several studies reveal correlations between rates of illness and room views of natural landscapes among institutional populations (e.g., prisoners). ${ }^{125,129}$ 
Children in day care settings with greater access to nature are less impulsive and concentrate better. ${ }^{132}$ Wells ${ }^{133}$ found similar results for residential access to nature in a longitudinal study comparing children who relocated. Children with attentional disorders (e.g., attention-deficit/hyperactivity disorder) have fewer behavioral problems when they spend more time in natural settings. ${ }^{134}$ Low-income housing areas in London with less access to private gardens have higher prevalence of depression, independent of SES, ${ }^{31}$ and public housing residents living adjacent to natural outdoor areas report better adjustment to their living environment, feel safer, and have more positive affect than others from the same housing development living near outdoor spaces devoid of nature. ${ }^{135}$

Design elements other than nature have the potential to enhance restorative processes within settings. Architectural features that support fascination, curiosity, or involuntary attention ought to enhance recovery from mental fatigue. Views of nature, fireplaces, fountains, aquariums, and animals (e.g., an aviary) as well as paintings of landscapes and other coherent, tranquil scenes are among the design elements with the potential to afford restoration. ${ }^{125,126,136,137}$ Spaces where people can briefly get away and be alone may buffer some of the harmful effects of residential crowding. ${ }^{138}$

\section{Summary}

Table 2 summarizes indirect connections between the built environment and mental health, suggesting that control, social support, and restoration may intercede between the physical environment and mental health. Note that only in a few cases (e.g., higher density $\rightarrow$ lower social support $\rightarrow$ increased psychological distress) has full mediation been tested. ${ }^{139,140}$ Instead, what exists is evidence for the initial link between the physical environment and the psychosocial mediator on the one hand, and between the psychosocial process and a mental health outcome on the other. I summarize in Table 2 evidence for the initial link in the indirect pathway, that is, correlations between the physical environment and each of these three hypothetical psychosocial mediators.

\section{CONCEPTUAL OVERVIEW AND RESEARCH AGENDA}

Several methodological challenges face research on the built environment and mental health. These challenges include self-selection (drift) of people into settings, inadequate environmental measurement, poor exposure estimation, overreliance on self-report indicators rather than objective markers of environmental quality, restricted variance in environmental quality, nonlinear relationships between environmental quality and well-being, and the embeddedness of different settings within one another (e.g., housing within neighborhood). On balance, these different methodological shortcomings do not sum to a readily discernible bias. Some of the problems (e.g., self-selection) may cause overestimation of the association between the built environment and mental health, whereas other problems (e.g., inadequate exposure estimation) would bias the results in the opposite direction.

Perhaps the most difficult intellectual challenge facing scholars and policymakers interested in the potential role of the built environment in mental health is the issue of underlying mechanisms or explanatory models. I have offered three hypothetical, underlying mechanisms: control, social support, and restoration. Clearly, more thought and analyses are necessary on why and how the physical environment might affect mental health. 
TABLE 2. Indirect mental health effects of the physical environment

\begin{tabular}{|c|c|c|c|}
\hline Indirect pathway & Environmental characteristic & Assessment of the evidence & References \\
\hline \multirow[t]{5}{*}{ Personal control } & Noise & $\begin{array}{l}\text { Laboratory and field (including one prospective and one intervention } \\
\text { study) show uncontrollable noise can induce helplessness. }\end{array}$ & $\begin{array}{r}42,51,77-79 \\
83-86\end{array}$ \\
\hline & Crowding & $\begin{array}{l}\text { Children living in higher density homes (people/room) have greater } \\
\text { learned helplessness. Similar findings among crowded adults in the } \\
\text { laboratory. }\end{array}$ & $42,80-82,87-89$ \\
\hline & Suite vs. corridor & $\begin{array}{l}\text { Students in long-corridor dormitories show greater learned helplessness } \\
\text { than those living in suite designs. Longitudinal, intervention, and } \\
\text { cross-sectional evidence. }\end{array}$ & $90-92$ \\
\hline & Spatial hierarchy & $\begin{array}{l}\text { Theoretical but little empirical evidence for claim that providing a } \\
\text { range of social interaction spaces (i.e., solitude to small group) fosters } \\
\text { better ability to regulate social interaction. }\end{array}$ & $95-96$ \\
\hline & Territoriality & $\begin{array}{l}\text { Numerous cross-sectional and a couple of intervention studies show } \\
\text { that multifamily residences that are tall, large, and have few semipri- } \\
\text { vate spaces (e.g., group territory), lead to feelings of lack of control } \\
\text { and are associated with crime. }\end{array}$ & 93-94, 99-102 \\
\hline \multirow[t]{3}{*}{ Social support } & Distance & $\begin{array}{l}\text { Physical proximity increases unplanned social interaction. Functional op- } \\
\text { portunities for interaction (e.g., doorway opening, proximity to pedes- } \\
\text { trian pathway) also afford greater social interaction. }\end{array}$ & $109-113$ \\
\hline & Crowding & $\begin{array}{l}\text { Laboratory and field (cross-sectional and prospective) data reveal that } \\
\text { higher density causes social withdrawal and the deterioration of so- } \\
\text { cially supportive relationships. }\end{array}$ & 42,117 \\
\hline & Housing & $\begin{array}{l}\text { High-rise housing and residence on high-traffic volume streets is associ- } \\
\text { ated with less interaction with neighbors. Cross-sectional data only. }\end{array}$ & $8,93,118-120$ \\
\hline \multirow{2}{*}{$\begin{array}{l}\text { Restoration and recovery } \\
\text { from cognitive fatigue and } \\
\text { stress }\end{array}$} & Natural elements & $\begin{array}{l}\text { Laboratory, field, and intervention studies converge on nature reducing } \\
\text { stress and diminishing cognitive fatigue. }\end{array}$ & $125-135$ \\
\hline & Architecture & $\begin{array}{l}\text { Design elements other than nature may have similar capabilities. Sa- } \\
\text { lient qualities include fascination, quiet and solitude, and coherent, } \\
\text { tranquil stimuli. Primarily theoretical arguments with little data. }\end{array}$ & $125,126,136-138$ \\
\hline
\end{tabular}


Another challenge is moderator effects. Nearly all of the empirical data reviewed report overall effects of a particular characteristic of the built environment (e.g., light) on some indicator of mental health. Yet we know that in many cases there is likely to be variability in individual reactions to the built environment. There is a dearth of information on this topic. Women, particularly low-income women with young children, may be more vulnerable to adverse psychological consequences of housing. ${ }^{4,6}$ The link between residential crowding and helplessness appears to be stronger in female than male children. ${ }^{42}$ Qualities of the physical environment can also interact with the social environment as they influence mental health. The negative effects of housing quality, ${ }^{141}$ residential crowding, ${ }^{142,143}$ noise, ${ }^{144}$ and air quality $^{145}$ on psychological health are all exacerbated by the presence of other social stressors such as family turmoil or interpersonal loss. Individuals already facing psychosocial stressors are more psychologically vulnerable to suboptimal environmental conditions.

In my discussion of housing quality and mental health, I briefly noted that lowquality housing is frequently embedded within distressed neighborhoods and thus presents methodological challenges to disentangle the source of mental health impacts. Some aspects of this issue have been addressed by studies examining the interaction of housing quality and neighborhood quality on mental health. Psychological distress in relation to inadequate housing is exacerbated among those living in more distressed neighborhoods. ${ }^{146,147}$ The negative association between residential crowding and mental health appears stronger among those residing in multifamily dwellings relative to single family or row houses. ${ }^{148}$ Crowded families living on higher floors of multifamily dwellings do worse than crowded families residing on lower floors. ${ }^{149,150}$ The well-documented relationship between crowding and negative emotional reactions is exacerbated by high temperatures. ${ }^{151}$ Children from more crowded homes manifest more behavioral problems in crowded day care centers than children in crowded day care centers who live in uncrowded homes. ${ }^{152}$ Finally, adults living in crowded residences in high-density neighborhoods manifest more psychological distress than adults living in crowded residences situated in low-density neighborhoods. ${ }^{153}$ Each of these studies demonstrates that exposure to multiple adverse physical and social conditions can combine to yield more negative mental health outcomes compared to exposure to individual environmental stressors.

Another important conceptual and analytic challenge in studying mental health and the built environment is socioeconomic status. Traditionally, SES has been treated as a confounding variable, requiring control in order to pinpoint the role of environmental risks in health. This view can be challenged in at least two respects. First, the natural ecology of environmental risk is strongly affected by SES. There is abundant evidence of environmental injustice showing that the poor and ethnic minorities are disproportionately likely to reside, attend work or school, and recreate in suboptimal environments relative to their more affluent counterparts. ${ }^{28,154}$ Second, cumulative social and environmental risk factors have substantially greater impact on health than singular risk factors. ${ }^{155,156}$ Moreover, the harmful impacts of poverty on health may be conveyed by cumulative environmental risk exposure. ${ }^{157}$ Thus the assessment of singular environmental risk factors is both nonrepresentative and likely underestimates the health consequences of poor environmental quality.

Obviously, researchers need more investigation with stronger research designs that incorporate good exposure measurement, ideally over time, and rely on appropriate indicators of psychological well-being. However, at this nascent stage of scholarship on the built environment and mental health, the most pressing need is 
better understanding of the psychosocial and biological processes that underlie the pathways potentially linking the built environment to mental health. Such an understanding would enable consideration of the most salient dimensions of the built environment along with contextual factors to be incorporated into more ecologically valid models of the built environment and mental health.

\section{ACKNOWLEDGEMENT}

Preparation of this article was partially supported by the Milbank Memorial Fund, the John D. and Catherine T. MacArthur Foundation Network on Socioeconomic Status and Health, and the William T. Grant Foundation.

\section{REFERENCES}

1. National Research Council. Indoor Air Pollutants. Washington, DC: National Academy Press; 1981.

2. Lawrence RJ. Healthy residential environments. In: Bechtel RB, Churchman A, eds. Handbook of Environmental Psychology. 2nd ed. New York, NY: Wiley; 2002;394412.

3. Matte TD. Housing and health: current issues and implications for research and programs. J Urban Health. 2000;77:7-25.

4. Evans GW, Wells NM, Moch A. Housing and mental health: a review of the evidence and a methodological and conceptual critique. J Soc Issues. 2003;59:475-500.

5. Freeman HL. Housing. In: Freeman HL, ed. Mental Health and the Environment. London, England: Churchill Livingstone; 1984:197-225.

6. Gifford R. Satisfaction, health, security, and social relationships in high-rise buildings. In: Seidel A, Heath T, eds. Social Effects of the Built Environment. London, England: E \& FN Spon. In press.

7. Fanning, DM. Families in flats. BMJ. 1967;4:382-386.

8. McCarthy D, Saegert S. Residential density, social overload, and social withdrawal. In: Aiello J, Baum A, eds. Residential Crowding and Design. New York, NY: Plenum; 1979:55-76.

9. Saegert S. Environments and children's mental health: residential density and low income children. In: Baum A, Singer JE, eds. Handbook of Psychology and Health. Hillsdale, NJ: Erlbaum; 1982:247-271.

10. Bartlett S. Does inadequate housing perpetuate children's poverty? Childhood. 1998; 5:403-420.

11. Stewart W. Children in Flats: A Family Study. London, England: National Society for the Prevention of Cruelty to Children; 1970.

12. Halpern D. Mental Health and the Built Environment. London, England: Taylor and Francis; 1995.

13. Carp FM. Impact of improved housing on morale and life satisfaction. Gerontologist. 1975;15:511-515.

14. Elton PJ, Packer J. A prospective, randomized trial of the value of rehousing on the grounds of mental health. J Chronic Dis. 1986;39:221-227.

15. Evans GW, Wells NM, Chan E, Saltzman H. Housing and mental health. J Consult Clin Psychol. 2000;68:526-530.

16. Christensen D, Carp FM, Crams G, Wiley J. Objective housing indicators as predictors of the subjective evaluation of elderly residents. J Environ Psychol. 1992;12:225-236.

17. Adam EK, Chase-Lansdale PL. Home sweet home(s): parental separations, residential moves, and adjustment problems in low-income girls. Dev Psychol. 2002;38:792-805.

18. Humke C, Schaefer C. Relocation: a review of the effects of residential mobility on children and adolescents. Psychol J Hum Behav. 1995;32:16-24. 
19. Lawton MP. Environment and Aging. Monterey, Calif: Brooks-Cole; 1980.

20. Fried M. Grieving for a lost home. In: Duhl L, ed. The Urban Condition. New York, NY: Basic; 1963:229-248.

21. Kearns A, Hiscock R, Ellaway A, Macintrye S. Beyond four walls. The psychosocial benefits of home: evidence from West Central Scotland. Housing Stud. 2000;15:387410.

22. Gielen AC, Wilson M, Faden R, Wissow L, Harvilchuck J. In-home injury prevention practices for infants and toddlers: the role of parental beliefs, barriers, and housing quality. Health Educ Q. 1995;22:85-95.

23. Macpherson A, Roberts I, Pless IB. Children's exposure to traffic and pedestrian injuries. Am J Public Health. 1998;88:1840-1845.

24. Mueller BA, Rivara FP, Lii SM, Weiss NS. Environmental factors and the risk for childhood pedestrian-motor vehicle collision occurrence. Am J Epidemiol. 1990;132: $550-560$.

25. O'Campo P, Rao RP, Gielen AC, Royalty W, Wilson M. Injury-producing events among children in low-income communities: the role of community characteristics. $J$ Urban Health. 2000;77:34-49.

26. Johnson MP, Ladd HF, Ludwig J. The benefits and costs of residential mobility programs for the poor. Housing Stud. 2002;17:125-138.

27. Dalgard OS, Tambs K. Urban environment and mental health: a longitudinal study. Br J Psychiatry. 1997;171:530-536.

28. Evans GW, Kantrowitz E. Socioeconomic status and health: the potential role of environmental risk exposure. Annu Rev Public Health. 2002;23:303-331.

29. Wandersman A, Nation M. Urban neighborhoods and mental health. Am Psychol. 1998;53:647-656.

30. Leventhal T, Brooks-Gunn J. Neighborhoods they live in: the effects of neighborhood residence on child and adolescent outcomes. Psychol Bull. 2000;126:309-337.

31. Weich S, Blanchard M, Prince M, Burton E, Erens B, Sproston K. Mental health and the built environment: cross sectional survey of individual and contextual risk factors for depression. Br J Psychiatry. 2002;176:428-433.

32. Holahan CJ. Seating patterns and patient behaviors in an experimental dayroom. $J$ Abnorm Psychol. 1972;80:115-124.

33. Holahan CJ, Saegert S. Behavioral and attitudinal effects of large scale variation in the physical environment of psychiatric wards. J Abnorm Psychol. 1972;82:454-462.

34. Osmond H. Function as the basis of psychiatric ward design. Ment Hospitals. 1957;8: 23-30.

35. Sommer R. Personal Space. Englewood Cliffs, NJ: Prentice-Hall; 1969.

36. Timko C. Physical characteristics of residential psychiatric and substance abuse programs: organizational determinants and patient outcomes. Am J Community Psychol. 1996;24:173-192.

37. Zimring C, Weitzer W, Knight RC. Opportunity for control and the designed environment. In: Baum A, Singer JE, eds. Advances in Environmental Psychology. Vol. 4. Hillsdale, NJ: Erlbaum; 1982:171-210.

38. Ittelson WH, Proshansky HM, Rivlin LG. The environmental psychology of the psychiatric ward. In: Proshansky HM, Ittelson WH, Rivlin LG, eds. Environmental Psychology. New York, NY: Holt, Rinehart and Winston; 1970:419-438.

39. Day K, Calkins MP. Design and dementia. In: Bechtel RB, Churchman A, eds. Handbook of Environmental Psychology. 2nd ed. New York, NY: Wiley; 2002:374-393.

40. Kuller R. Familiar design helps dementia patients cope. In: Preiser WFE, Vischer JC, White ET, eds. Design Intervention. New York, NY: Van Nostrand; 1991:255-268.

41. Baum A, Paulus PB. Crowding. In: Stokols D, Altman I, eds. Handbook of Environmental Psychology. New York, NY: Wiley; 1987:533-570.

42. Evans GW. Environmental stress and health. In: Baum A, Revenson T, Singer JE, eds. Handbook of Health Psychology. Mahwah, NJ: Erlbaum; 2001:571-610. 
43. Paulus PB. Prison Crowding: A Psychological Perspective. New York, NY: Springer; 1988.

44. Wener RE, Keys C. The effects of changes in jail population densities on crowding, sick call, and social behavior. J Appl Soc Psychol. 1988;18:852-866.

45. Evans GW, Lepore SJ, Allen KM. Cross-cultural differences in tolerance for crowding: fact or fiction? J Pers Soc Psychol. 2000;79:204-210.

46. Evans GW, Lercher P, Meis M, Ising H, Kofler W. Community noise exposure and stress in children. J Acoustical Soc Am. 2001;109:1023-1027.

47. Gove WR, Hughes M. Overcrowding in the Household. New York, NY: Academic; 1983.

48. Lepore SJ, Evans GW, Schneider M. The dynamic role of social support in the link between chronic stress and psychological distress. J Pers Soc Psychol. 1991;61:899_ 909.

49. Stansfeld SA. Noise, noise sensitivity, and psychiatric disorder: epidemiological and psychophysiological studies. Psychol Med, Monogr Suppl. 1993;22:1-44.

50. Lercher P, Evans GW, Meis M, Kofler W. Ambient neighborhood noise and children's mental health. Occup Environ Med. 2002;59:380-386.

51. Bullinger M, Hygge S, Evans GW, Meis M, van Mackensen S. The psychological cost of aircraft noise for children. Zentralblatt Hygiene Umweltmedizin. 1999;202:127-138.

52. Grandjean E, Graf P, Lauber A, Meier H, Muller R. Survey on the effects of noise around three civil airports in Switzerland. In: Kerlin R, ed. Internoise '76. Washington, DC: Institute of Noise Control Engineers; 1976:85-90.

53. Knipschild P, Oudshoorn N. VII. Medical effects of aircraft noise: drug survey. Int Arch Occup Environ Health. 1977;40:197-200.

54. Haines MM, Stansfeld SA, Brenthall S, et al. The West London schools study: the effects of chronic noise exposure on child health. Psychol Med. 2001;31:1385-1396.

55. Haines MM, Stansfeld SA, Job RFS, Berglund B, Head J. A follow-up study of effects of chronic aircraft noise exposure on child stress responses and cognition. Int J Epidemiol. 2001;30:839-845.

56. Haines MM, Stansfeld SA, Job RFS, Berglund B, Head J. Chronic aircraft noise exposure, stress responses, mental health and cognitive performance in school children. Psychol Med. 2001;31:265-277.

57. Evans GW. The psychological costs of chronic exposure to ambient air pollution. In: Isaacson RL, Jensen KF, eds. The Vulnerable Brain and Environmental Risks. New York, NY: Plenum; 1994:167-182.

58. Rotton J, Cohn EG. Climate, weather, and crime. In: Bechtel RB, Churchman A, eds. Handbook of Environmental Psychology. 2nd ed. New York, NY: Wiley; 2002:481-498.

59. Rotton J. Affective and cognitive consequences of malodorous pollution. Basic Appl Soc Psychol. 1983;4:171-191.

60. Cavalini P, Koeter-Kemmerling L, Pulles TM. Coping with odor annoyance and odor concentrations. J Environ Psychol. 1991;11:123-142.

61. Araki S. Neurobehavioral Methods and Effects in Occupational and Environmental Health. New York, NY: Academic; 1994.

62. Needleman HL, Gunnoe C, Leviton A, et al. Deficits in psychological and classroom performance of children with elevated dentine lead levels. N Engl J Med. 1979;300: 689-695.

63. Needleman HL, Schell A, Bellinger D, Leviton A, Allred E. The long term effects of low doses of lead in childhood: an 11 year follow up report. N Engl J Med. 1989;322: 83-88.

64. Sciarillo WG, Alexander G, Farrell KP. Lead exposure and child behavior. Am J Public Health. 1992;82:1356-1360.

65. Bell IR, Baldwin CM, Schottenfeld RS. Psychological sequelae of hazardous materials exposure. In: Sullivan JB, Krieger GR, eds. Clinical Environmental Health and Toxic Exposures. 2nd ed. Philadelphia, Pa: Lippincott Williams and Wilkins; 2001:404-412. 
66. Masters RD, Hone B, Doshi A. Environmental pollution, neurotoxicity, and criminal violence. In: Rose J, ed. Environmental Toxicology. New York, NY: Gordon and Breach; 1998:13-48.

67. Laughlin NK. Animal models of behavioral effects of early lead exposure. In: Riley EP, Vorhess CV, eds. Handbook of Behavioral Teratology. New York, NY: Plenum; 1986: 291-320.

68. Edelstein MR. Contaminated Communities. Boulder, Colo: Westview; 1988.

69. Edelstein MR. Contamination: the invisible built environment. In: Bechtel RB, Churchman A, eds. The Handbook of Environmental Psychology. 2nd ed. New York, NY: Wiley; 2002:559-588.

70. Rosenthal NE, Sack DA, Gillin JC, et al. Seasonal affective disorder. Arch Gen Psychiatry. 1984;41:72-80.

71. Beauchemin KM, Hays P. Sunny hospital rooms expedite recovery from severe and refractory depressions. J Affective Disord. 1996;40:49-51.

72. McColl SL, Veitch JA. Full spectrum fluorescent lighting: a review of its effects on physiology and health. Psychol Med. 2001;31:949-964.

73. Kuller R, Lindsten C. Health and behavior of children in classrooms with and without windows. J Environ Psychol. 1992;12:305-317.

74. Bandura A. Self Efficacy. San Francisco, Calif: W.H. Freeman; 1987.

75. Shapiro DH, Astin J. Control Therapy. New York, NY: Wiley; 1998.

76. Taylor SE, Brown JD. Illusions and well being: a social psychological perspective on mental health. Psychol Bull. 1988;103:193-210.

77. Glass DC, Singer JE. Urban Stress. New York, NY: Academic; 1972.

78. Hiroto D. Locus of control and learned helplessness. J Exp Psychol. 1974;102:187193.

79. Krantz DS, Glass DC, Snyder M. Helplessness, stress level, and coronary prone behavior pattern. J Exp Soc Psychol. 1974;10:284-300.

80. Evans GW. Behavioral and physiological consequences of crowding in humans. J Appl Soc Psychol. 1979;9:27-46.

81. Nicosia G, Hyman D, Karlin R, Epstein Y, Aiello J. Effects of bodily contact on reactions to crowding. J Appl Soc Psychol. 1979;9:508-523.

82. Sherrod D. Crowding, perceived control, and behavioral aftereffects. J Appl Soc Psychol. 1974;4:171-186.

83. Cohen S, Evans GW, Stokols D, Krantz DS. Behavior, Health, and Environmental Stress. New York, NY: Plenum; 1986.

84. Evans GW, Hygge S, Bullinger M. Chronic noise and psychological stress. Psychol Sci. 1995;6:333-338.

85. Moch A. Study of the effects of noise on the personality and certain intellectual and psychomotor aspects of children. Travail Human. 1981;44:170-178.

86. Maxwell LE, Evans GW. The effects of noise on preschool children's prereading skills. J Environ Psychol. 2000;20:91-97.

87. Fleming I, Baum A, Weiss L. Social density and perceived control as mediators of crowding stress in high density neighborhoods. J Pers Soc Psychol. 1987;52:899_ 906.

88. Evans GW, Lepore SJ, Sejwal B, Palsane MN. Chronic residential crowding and children's well being: an ecological perspective. Child Dev. 1998;69:1514-1523.

89. Rodin J. Density, perceived choice, and response to controllable and uncontrollable outcomes. J Exp Soc Psychol. 1976;12:564-578.

90. Baum A, Valins S. Architecture and Social Behavior. Hillsdale, NJ: Erlbaum; 1977.

91. Baum A, Valins S. Architectural mediation of residential density and control: crowding and the regulation of social contact. In: Berkowitz L, ed. Advances in Experimental Social Psychology. New York, NY: Academic; 1979.

92. Baum A, Gatchel R, Aiello J, Thompson D. Cognitive mediation of environmental stress. In: Harvey J, ed. Cognition, Social Behavior, and the Environment. Hillsdale, NJ: Erlbaum; 1981:513-533. 
93. Churchman A, Ginsberg Y. The image and experience of high rise housing in Israel. $J$ Environ Psychol. 1984;4:27-41.

94. Evans GW, Saltzman H, Cooperman J. Housing quality and children's socioemotional health. Env Behav. 2001;33:389-399.

95. Alexander C. The city as a mechanism for sustaining human contact. In: Gutman R, ed. People and Buildings. New York, NY: Basic; 1972:406-434.

96. Zimring C. The built environment as a source of psychological stress: impacts of buildings and cities on satisfaction and behavior. In: Evans GW, ed. Environmental Stress. New York, NY: Cambridge; 1982:151-198.

97. Evans GW, Lepore SJ, Schroeder A. The role of architecture in human responses to crowding. J Pers Soc Psychol. 1996;70:41-46.

98. Peponis J, Wineman J. Spatial structure of environment and behavior. In: Bechtel RB, Churchman A, eds. Handbook of Environmental Psychology. 2nd ed. New York, NY: Wiley; 2002:271-291.

99. Nasar JL, Fisher B. Hot spots of fear and crime: a multi-method investigation. J Environ Psychol. 1993;13:187-206.

100. Newman O. Defensible Space. New York, NY: Macmillan; 1972.

101. Taylor RB. Human Territorial Functioning. New York, NY: Cambridge University Press; 1988.

102. Taylor RB. Crime prevention through environmental design. In: Bechtel RB, Churchman A, eds. Handbook of Environmental Psychology. 2nd ed. New York, NY: Wiley; 2002:413-426.

103. Sampson RJ, Raudenbush SW, Earls F. Neighborhoods and violent crime: a multilevel study of collective efficacy. Science. 1997;277:918-924.

104. Rosenbaum JE, Reynolds L, Deluca S. How do places matter? The geography of opportunity, self-efficacy, and a look inside the black box of residential mobility. Housing Stud. 2002;17:71-82.

105. Cohen S, Gottlieb BH, Underwood LG. Social relationships and health. In: Cohen S, Underwood LG, Gottlieb BH, eds. Social Support Measurement and Intervention. New York, NY: Oxford University Press; 2000:3-28.

106. Cohen S, Syme SL, eds. Social Support and Health. New York, NY: Academic; 1985.

107. Kawachi I, Bergman LF. Social ties and mental health. J Urban Health. 2001;78:458467.

108. Vaux A. Social Support: Theory, Research, and Intervention. New York, NY: Praeger; 1988.

109. Fleming R, Baum A, Singer JE. Social support and the physical environment. In: Cohen S, Syme L, eds. Social Support and Health. New York, NY: Academic; 1985:327-346.

110. Moos RH. The Human Context. New York, NY: Wiley; 1976.

111. Becker FD. Workplace by Design. San Francisco, Calif: Jossey-Bass; 1995.

112. McCoy JM. Work environments. In: Bechtel RB, Churchman A, eds. Handbook of Environmental Psychology. 2nd ed. New York, NY; Wiley; 2002:443-460.

113. Sundstrom E. Workplaces. New York, NY: Cambridge University Press; 1986.

114. Bechtel RB. Enclosing Behavior. Stroudsburg, Pa: Dowden, Hutchinson, and Ross; 1976.

115. Carr S, Francis M, Rivlin LG, Stone A. Public Space. New York, NY: Cambridge; 1992.

116. Whyte WH. The Social Life of Small Urban Spaces. Washington, DC: Conservation Foundation; 1980.

117. Evans GW, Lepore SJ. Household crowding and social support: a quasi-experimental analysis. J Pers Soc Psychol. 1993;65:308-316.

118. Holahan CJ. Environment and Behavior. New York, NY: Plenum; 1978.

119. Wilcox BL, Holahan CJ. Social ecology of the megadorm in university student housing. J Educ Psychol. 1976;68:453-458.

120. Appleyard D, Lintell M. The environmental quality of city streets. J Am Inst Planners. 1972;38:84-101. 
121. Berglund B, Lindvall T, Schewela D. Guidelines for Community Noise. Geneva, Switzerland: World Health Organization; 2000.

122. Kryter K. The Handbook of Hearing and the Effects of Noise. New York, NY: Academic; 1994.

123. Medical Research Council. The Nonauditory Effects of Noise. Report R10, Institute for Environment and Health. Leicester, England: University of Leicester; 1997.

124. Cohen S, Spacapan S. The social psychology of noise. In: Jones DM, Chapman AJ, eds. Noise and Society. Chichester, England: Wiley; 1984:221-245.

125. Kaplan R, Kaplan S. The Experience of Nature. New York, NY: Cambridge University Press; 1984.

126. Kaplan R, Kaplan S, Ryan RL. With People in Mind. Washington, DC: Island Press; 1998.

127. Kuo FE. Coping with poverty. Env Behav. 2001;33:5-34.

128. Parsons R, Hartig T. Environmental psychophysiology. In: Cacioppo JT, Tassinary LG, Berntson GG, eds. Handbook of Psychophysiology. 2nd ed. New York, NY: Cambridge University Press; 2000:815-846.

129. Ulrich RS. Biophilia, biophobia, and natural landscapes. In: Kellert SR, Wilson EO, eds. The Biophilia Hypothesis. Washington, DC: Island Press; 1993:73-137.

130. Larsen L, Adams J, Deal B, Kweon BS, Tyler E. Plants in the workplace. Env Behav. 1998;30:261-281.

131. Ulrich RS. View through a window may influence recovery from surgery. Science. 1984;224:420-421.

132. McCarney SB. The Attention Deficit Disorders Evaluation Scale (ADDES): Home Version Technical Manual. 2nd ed. Columbia, Mo: Hawthorne Educational Services; 1995.

133. Wells NM. At home with nature: effects of "greenness" on children's cognitive functioning. Env Behav. 2000;32:775-795.

134. Kuo FE. Bridging the gap: how scientists can make a difference. In: Bechtel RB, Churchman A, eds. Handbook of Environmental Psychology. 2nd ed. New York, NY: Wiley; 2002.

135. Kuo FE, Sullivan WC, Coley R, Brunson L. Fertile ground for community: inner-city neighborhood common spaces. Am J Community Psychol. 1998;26:823-851.

136. Frumkin H. Beyond toxicity: human health and the natural environment. Am J Prev Med. 2001;20:234-240.

137. Ulrich RS. Effects of interior design on wellness: theory and recent scientific research. J Health Care Interior Design. 1991;3:97-109.

138. Wachs TD, Gruen G. Early Experience and Human Development. New York, NY: Plenum; 1982.

139. Baron RM, Kenny DA. The moderator-mediator variable distinction in social psychological research: conceptual, strategic, and statistical considerations. J Pers Soc Psychol. 1986;51:1173-1182.

140. Evans GW, Lepore SJ. Moderating and mediating processes in environment behavior research. In: Moore GT, Marans RW, eds. Advances in Environment, Behavior, and Design. Vol. 4. New York, NY: Plenum; 1997.

141. Earls M, Nelson G. The relationship between long term psychiatric clients' psychological well being and their perceptions of housing and social support. Am J Community Psychol. 1988;16:279-293.

142. Evans GW, Saegert S. Residential crowding in the context of inner city poverty. In: Wapner S, Demick J, Minami H, Yamamoto T, eds. Theoretical Perspectives in Environment-Behavior Research. New York, NY: Plenum; 2000:247-268.

143. Lepore SJ, Evans GW, Palsane MN. Social hassles and chronic strains: a hierarchy of stressors? J Health Soc Behav. 1991;32:357-367.

144. Evans GW, Allen K, Tafalla R, O’Meara T. Multiple stressors: performance, psychophysiologic, and affective responses. J Environ Psychol. 1996;16:65-74. 
145. Evans GW, Jacobs SV, Dooley C, Catalano R. The interaction of stressful life events and chronic strains on community mental health. Am J Community Psychol. 1987;15: 23-34.

146. Kasl SW, Will J, White M, Marcuse P. Quality of the residential environment and mental health. In: Baum A, Singer JE, eds. Advances in Environmental Psychology. Vol. 1. Hillsdale, NJ: Erlbaum; 1982:1-30.

147. McCarthy P, Byrne D, Harrison S, Keithley J. Housing type, housing location, and mental health. Soc Psychiatry. 1985;2:125-130.

148. Evans GW, Lercher P, Kofler W. Crowding and children's mental health: the role of house type. J Environ Psychol. 2002;22:221-232.

149. Hassan R. Social and psychological implications of high population density. Civilization. 1976;26:9-28.

150. Mitchell RE. Some social implications of high density housing. Am Sociol Rev. 1971; 36:18-29.

151. Ruback RB, Pandey J. Very hot and really crowded. Env Behav. 1992;24:527-554.

152. Maxwell LE. Multiple effects of home and day care crowding. Env Behav. 1996;28: 494-511.

153. Gomez-Jacinto L, Hombrados-Mendieta I. Multiple effects of community and household crowding. J Environ Psychol. 2002;22:223-246.

154. Frumkin H, Walker D. Minority workers and communities. In: Wallace R, ed. Maxcy Rosenau Last Public Health and Preventative Medicine. 14th ed. Stamford, Conn: Appleton and Lange; 1998:682-688.

155. Repetti RL, Taylor SE, Seeman TE. Risky families: family social environments and the mental and physical health of offspring. Psychol Bull. 2002;128:330-366.

156. Taylor SE, Repetti RL, Seeman TE. Health psychology: what is an unhealthy environment and how does it get under the skin? Annu Rev Psychol. 1997;48:411-447.

157. Evans GW, English K. The environment of poverty: multiple stressor exposure, psychophysiological stress, and socioemotional health. Child Dev. 2002;73:1238-1248. 